\title{
Synthesis on research results of FGD gypsum briquetting
}

\author{
Bogdan Kosturkiewicz ${ }^{1 *}$, Andrzej Janewicz ${ }^{1}$, Marek Hryniewicz ${ }^{1}$, and Lukasz \\ Kosturkiewicz ${ }^{2}$ \\ ${ }^{1}$ AGH University of Science and Technology, Faculty of Mechanical and Robotics, al. Mickiewicza 30, \\ 30-059 Cracow, Poland \\ ${ }^{2}$ Trzuskawica S.A., Sitkówka 24, 26-052 Nowiny
}

\begin{abstract}
FGD gypsum products can be characterized by significant solubility in water and dusting in dry state. These characteristics can cause a considerable pollution of air, water and soil. Among many approaches of preparing utilization of this waste, the process of compaction using briquetting has proved to be very effective. Using FGD gypsum products a new material of fertilizers characteristics has been acquired and this material is resistant to the conditions of transportation. This paper presents results of experimental briquetting of flue gas desulphurisation products in a roll press. The experiments were conducted in a laboratory roll presses LPW 450 and LPW 1100 equipped with two interchangeable forming rings that form material into saddle-shaped briquettes with volume $6,5 \mathrm{~cm}^{3}$ and $85 \mathrm{~cm}^{3}$. The experiments were conducted with various percentage amounts of FGD gypsum moisture. The results provided information regarding influence of moisture and roll press configuration on quality of briquettes. On the basis of obtained results, technological process and a general outline of technological line for FGD gypsum were developed. Two roll presses of own construction with different outputs were identified as appropriate for this purpose. A range of necessary works related to their adaptation for the FGD gypsum briquetting were pointed out.
\end{abstract}

\section{Introduction}

Due to increasingly strict environmental standards set out in the Directive [1], regarding industrial emissions 2010/75/UE (the so-called Directive IED), power plants are forced to reduce the amount of sulfur dioxide emission. The overall amount of sulfur dioxide emitted by Polish industry decreased from 1040 thousand Mg. in 2000 to 401 thousand Mg. in 2014 [2]. The most commonly used method of $\mathrm{SO}_{\mathrm{x}}$ disposal is the wet process of desulphurization used widely in conventional power plants (about $78 \%$ of all installations worldwide [3]). It is based on the absorption of sulfur dioxide in water-limestone slurry and its reaction with calcium carbonate. The product of this reaction is synthetic gypsum in the form of calcium sulfate dihydrate crystals, referred as FGD gypsum (Flue Gas Desulphurisation). Technical and commercial usage of FGD gypsum is currently limited

\footnotetext{
* Corresponding author: kostur@agh.edu.pl
} 
due to the surplus of demand over supply, furthermore due to transportation difficulties there is an idea to compact FGD gypsum. The subject was undertaken at the Department of Manufacturing Systems, AGH University of Science and Technology in Cracow. The results are presented in this article.

\section{Experimental}

The study focused on two kinds of FGD gypsum from two power plants - one from Połaniec and second from Bełchatów. FGD gypsum was homogenized in laboratory mixer with heated water jacket i.e. moisture and granulation was nearly the same in each sample. The chemical composition of mixture shown in table 1 .

Table 1. Chemical composition of FGD gypsum.

\begin{tabular}{|l|c|c|}
\hline \multirow{2}{*}{ Ingredient } & \multicolumn{2}{|c|}{ Value, \% } \\
\cline { 2 - 3 } & $\begin{array}{c}\text { Polaniec } \\
\text { power plants }\end{array}$ & $\begin{array}{c}\text { Belchatów power } \\
\text { plants }\end{array}$ \\
\hline $\mathrm{CaSO}_{4} \cdot 2 \mathrm{H}_{2} \mathrm{O}$ & $\sim 90$ & $\sim 90.8$ \\
\hline $\mathrm{Na}_{2} \mathrm{O}$ & $<0.06$ & $<0.05$ \\
\hline $\mathrm{K}_{2} \mathrm{O}$ & $<0.07$ & $<0.11$ \\
\hline $\mathrm{Al}_{2} \mathrm{O}_{3}$ & $<0.30$ & $<0.22$ \\
\hline $\mathrm{Fe}_{2} \mathrm{O}_{3}$ & $<0.15$ & $<0.21$ \\
\hline $\mathrm{SiO}_{2}$ & $<0.50$ & $<0.48$ \\
\hline $\mathrm{CaCO}_{3}+\mathrm{Mg} \mathrm{CO}_{3}$ & $<1.50$ & $<1.40$ \\
\hline $\mathrm{CaSO}_{3} \cdot 2 \mathrm{H}_{2} \mathrm{O}$ & $<0.50$ & $<0.51$ \\
\hline chlorides & $<0.01$ & $<0.01$ \\
\hline $\mathrm{H}_{2} \mathrm{O}$ & $<10$ & $<10$ \\
\hline
\end{tabular}

The chemical analysis of FGD gypsum was performed by using a spectrometer MiniPal 4 type: PW4025/00 (by PANanlitycal). Mixing and drying time was dependent on the moisture level of the material. Moisture content of gypsum determines the weight method. Briquetted material had moisture content of $2.3-30.6 \%$ and bulk density of $0.69-0.91 \mathrm{~g} / \mathrm{cm}^{3}$ (the lower humidity, the lesser bulk density). Briquetting of FGD gypsum was performed in a laboratory roll press LPW 450 with roller diameter of $450 \mathrm{~mm}$, equipped with two types of interchangeable molding rings capable of producing briquettes in a saddle-shape with volume of $4 \mathrm{~cm}^{3}$ (variant I) or $6.5 \mathrm{~cm}^{3}$ (variant II) and laboratory roll press LPW1100 (variant II) with possibility of forming saddle-shaped briquettes with volume of $85 \mathrm{~cm}^{3}$. Graphical visualization of forming rings are shown in Fig. 1.

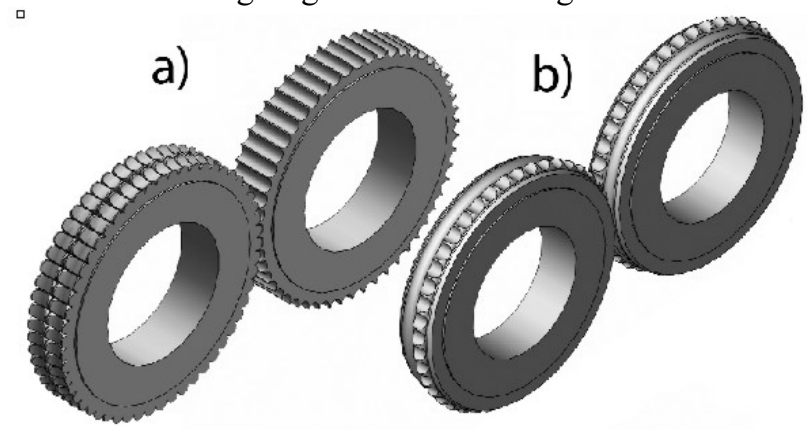

Fig.1. Models of forming rings: a) variant I, b) variant II. 
More detailed description of the testing installation located in Laboratory of Departament of Manufacturing Systems AGH was featured in previous article [4].

During the evaluation process of FGD gypsum compactibility, the first determined parameters were moisture content and compacting characteristics of the material. Compaction degree was determined by dividing the volume of sampled material before merging to the volume of briquettes at certain measurement point for a given unit pressure. Characteristics of compaction were digressive with compaction degree increasing with moisture - Fig. 2.

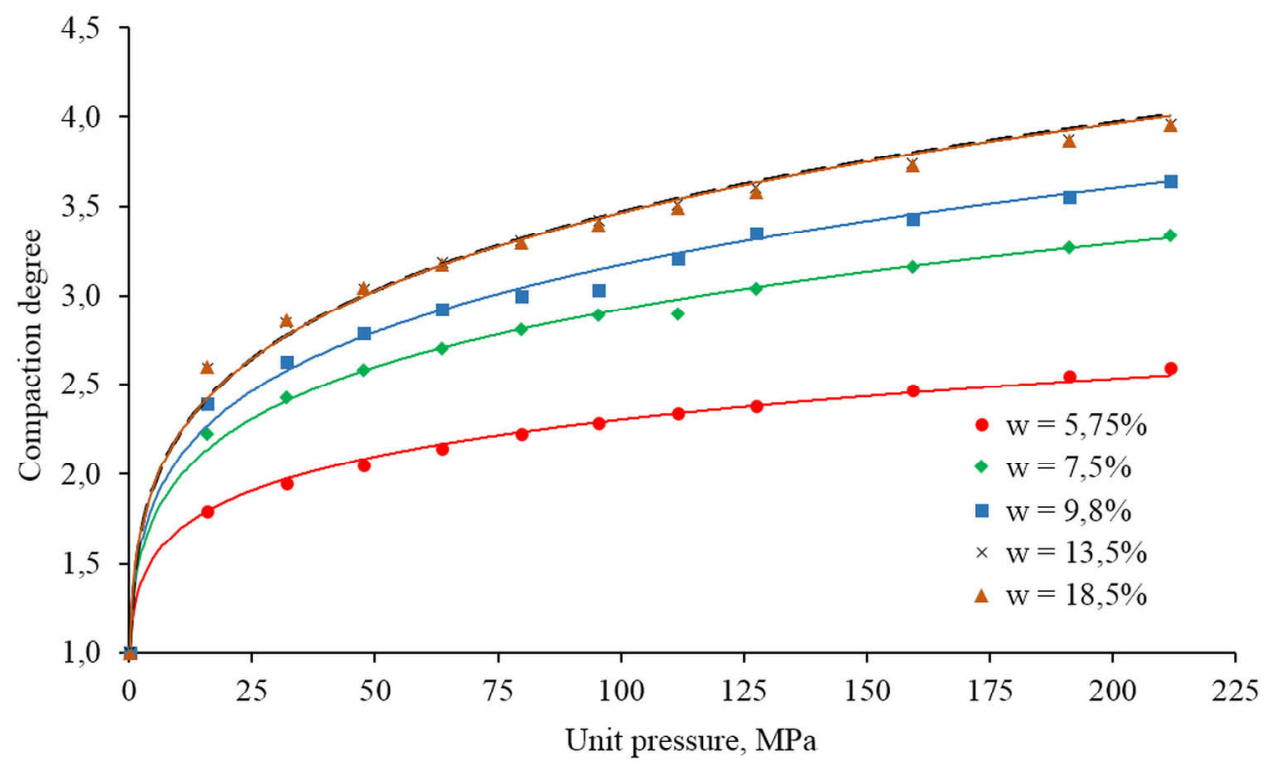

Fig.2. Compression characteristics of FGD gypsum from Połaniec power plants.

High value measured during the tests pointed need for a roll press equipped with asymmetrical compaction layout. Amount of material used for a single compaction was 9$11 \mathrm{~kg}$. Composition of the test materials are given in Table 2.

Table 2. Characteristic of trials.

\begin{tabular}{|c|c|c|c|c|}
\hline $\begin{array}{c}\text { Symbol } \\
\text { of trial }\end{array}$ & $\begin{array}{c}\text { Peripheral } \\
\text { speed of } \\
\text { rolls, } \\
\text { m/s }\end{array}$ & $\begin{array}{c}\text { Model of } \\
\text { forming } \\
\text { rings }\end{array}$ & $\begin{array}{c}\text { Briquette } \\
\text { volume, } \\
\mathbf{c m}^{3}\end{array}$ & $\begin{array}{c}\text { Plant of } \\
\text { origin }\end{array}$ \\
\hline A & 0.1 & I & 4.0 & $\begin{array}{c}\text { Połaniec } \\
\text { power plants }\end{array}$ \\
\hline B & 0.1 & II & 6.5 & $\begin{array}{c}\text { Połaniec } \\
\text { power plants }\end{array}$ \\
\hline C & 0.3 & II & 6.5 & $\begin{array}{c}\text { Połaniec } \\
\text { power plants }\end{array}$ \\
\hline D & 0.3 & II & 6.5 & $\begin{array}{c}\text { Bełchatów } \\
\text { power plants }\end{array}$ \\
\hline E & 0.3 & II & 85.0 & $\begin{array}{c}\text { Bełchatów } \\
\text { power plants }\end{array}$ \\
\hline
\end{tabular}

Briquettes were formed with a peripheral speed of rolls $v_{\mathrm{w}}=0.1$ and $0.3 \mathrm{~m} / \mathrm{s}$, which corresponds to rotation velocity $n_{\mathrm{w}}=4.24$ and $12.73 \mathrm{rpm}$. During compacting the initial gap between the rollers was approx. 1,0 $\mathrm{mm}$. Depending on its moisture content material passed 
through the rollers once or twice during the process. FGD gypsum with moisture of 2.39.1\% passed through the rolls once, while moisture content of $21.5-30.6 \%$ passed twice.

Briquettes in shape of molding cavities (saddle-shaped briquettes) were formed from the material with moisture content between $2.3-25.0 \%$ (Fig. 3).

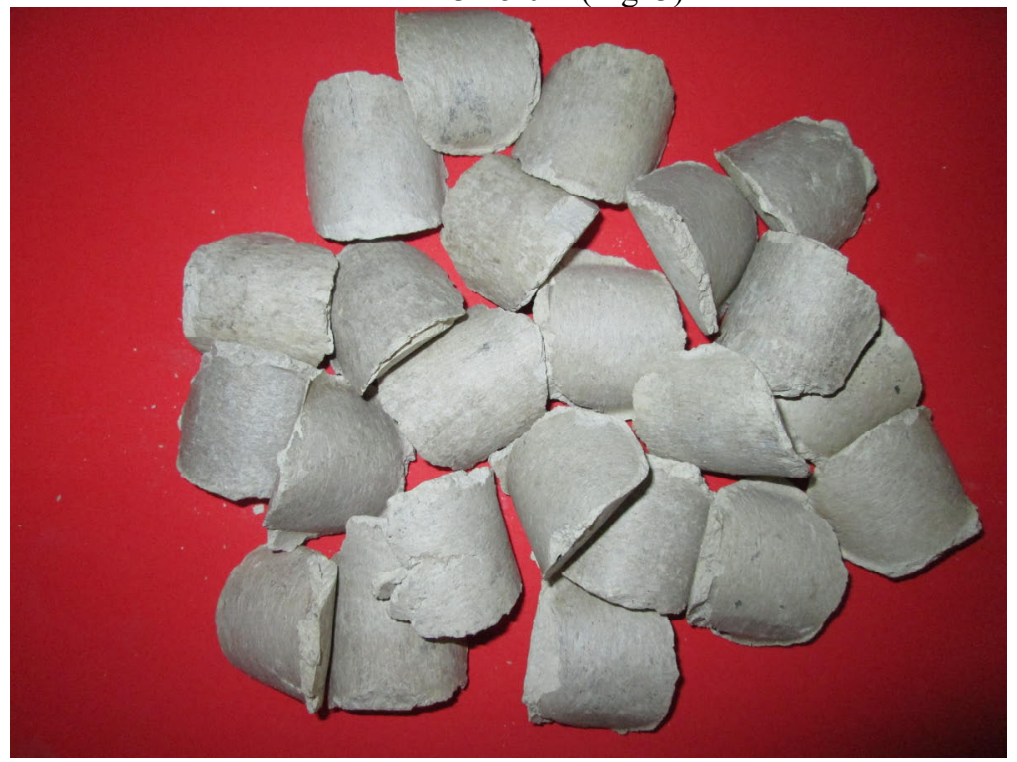

Fig. 3. FGD gypsum from Połaniec power plants briquettes (volume- $6,5 \mathrm{~cm}^{3}$ ) produced in roll press.

Material with moisture exceeding 25.0\% failed to form briquettes. During the merging operation following parameters were measured: a torque to the shaft of the roll press $\left(M_{\mathrm{t}}\right)$ and the specific pressure in the forming cavity $\left(p_{\mathrm{f}}\right)$.

Torque value was recorded by using a measuring circuit composed of Telemetry kit MT 2555 and preamplifier EV 2510 Hottinger Baldwin Messtechnik.

After leaving the cavities, the briquettes were stored in a container from which samples were taken at random (in batches 10 pcs. each) in order to determine parameters characterising their mechanical properties. The following properties were determined for the obtained briquettes: the density $\left(\rho_{\mathrm{b}}\right)$, strength to drop right after the test $\left(K_{0}\right)$, drop strength after $168 \mathrm{~h}\left(K_{168}\right)$ and compressive strength after $168 \mathrm{~h}\left(D_{168}\right)$ (for FGD gypsum with moisture content of 21.5-30.6\%).

Considering the loads character the briquettes are endangered to during their reloading, transportation and thermal management, it was decided that indexes that reflect their resistance to destruction at best shall be: compression strength and resistance to drop. Compressive strength tests of briquettes were performed at the measurement stand equipped with ZWICK 1120 press of pressure range $0 \div 2000 \mathrm{~N}$. The briquette was crushed slowly between two flat, parallel metal plates with facial areas greater than the projected area of the briquette. The speed rate of the upper plate was $0,001 \mathrm{~m} / \mathrm{s}$. The test for compressive strength, the crushing load (in N) was measured on 10 briquettes from each batch and the average value converted to compressive strength (in MPa) according equation $[5,6]$ :

$$
D=\frac{\text { Crushing load }}{\text { Cross }- \text { sectional area of plane of fracture }}, \mathrm{MPa}
$$

The strength to drop tests were performed after $168 \mathrm{~h}$ seasoning in order to minimize the influence of atmospheric conditions (humidity, temperature) on the value of obtained results. Durability of briquettes is determined by ASTM Method D440-86 (Drop Shatter for 
Coal). The briquettes were dropped from a height of $2 \mathrm{~m}$ onto a stell plate, $60 \mathrm{~mm}$ thicks. This test was performed three times, each time sieving the broken mass at a sieve of mesh $18 \times 18 \mathrm{~mm}$. Size of sieve was determined to $2 / 3$ of average calculated from two maximum briquette dimensions measured in mutually perpendicular directions.

\section{Results and discussion}

Test results were processed statistically according to procedures specified for the estimation carried out by evaluation in points.

Based on the results it was possible to indicate the quality of produced briquettes. Crucial parameter for briquettes obtained from FGD gypsum is their strength to drop which determines availability for product transport. The test results of FGD gypsum briquetting in roll-press are shown in fig. 4,5,6 and 7.

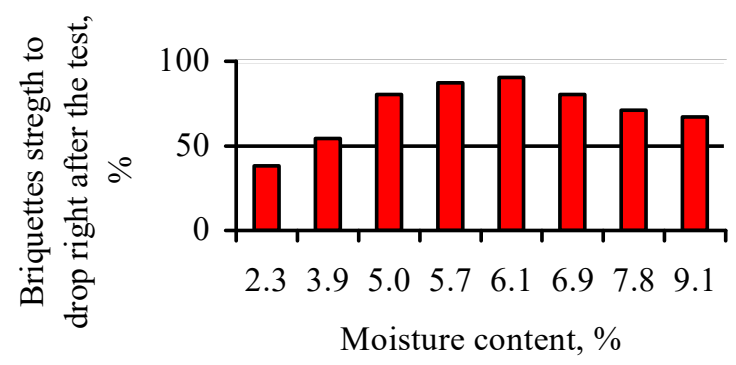

Fig.4. Effect of FGD gypsum from Połaniec power plants humidity on strength of briquettes to drop right after the test, trial C.

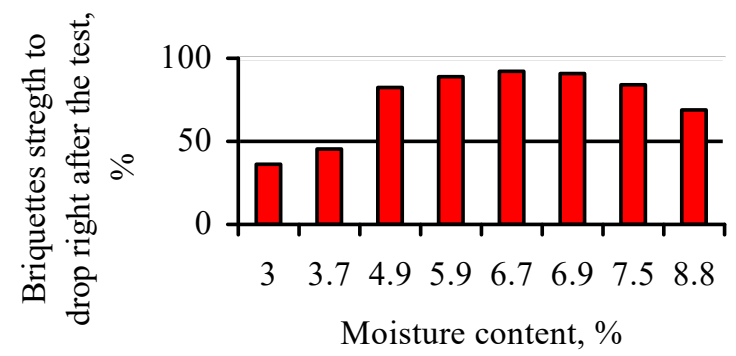

Fig. 5. Effect of FGD gypsum from Bełchatów power plants humidity on strength of briquettes to drop right after the test, trial $\mathrm{D}$.

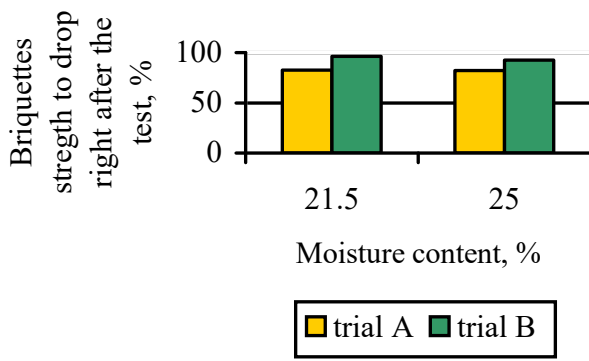

Fig. 6. Effect of FGD gypsum from Połaniec power plants humidity on strength of briquettes to drop right after the test. 

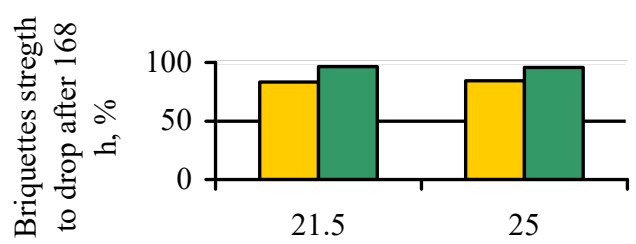

Moisture content, \%

$\square$ trial A $\square$ trial B

Fig. 7. Effect of FGD gypsum from Połaniec power plants humidity on strength of briquettes to drop after $168 \mathrm{~h}$.

Initial strength to drop of briquettes measured directly after merging was $38.1-90.4 \%$ in case of FGD gypsum with moisture of $2.3-9.1 \%$ and $80.0-96.4 \%$ for FGD gypsum with moisture of $21.5-30.6 \%$. After a brief seasoning of $168 \mathrm{~h}$, strength to drop of briquettes has increased slightly.

Unitary energy consumption during the briquetting process in a laboratory press equipped with gravity feeder amounted to $17.89-30.96 \mathrm{kWh} / \mathrm{Mg}$. Those calculations were carried out based on torque values on the shaft of the press.

Power consumed during briquetting process $N_{\mathrm{b}}$ was determined by the relation:

$$
N_{\mathrm{b}}=2 \cdot\left(M_{\mathrm{t}} \cdot n_{\mathrm{r}}\right) / 9.55, \mathrm{~kW}
$$

where: $M_{\mathrm{t}}$ - torque moment on a roll press, $\mathrm{kNm} ; n_{\mathrm{r}}$ - roll press rotational speed, rpm.

Example of time characteristic for the torque was shown in Fig. 8.

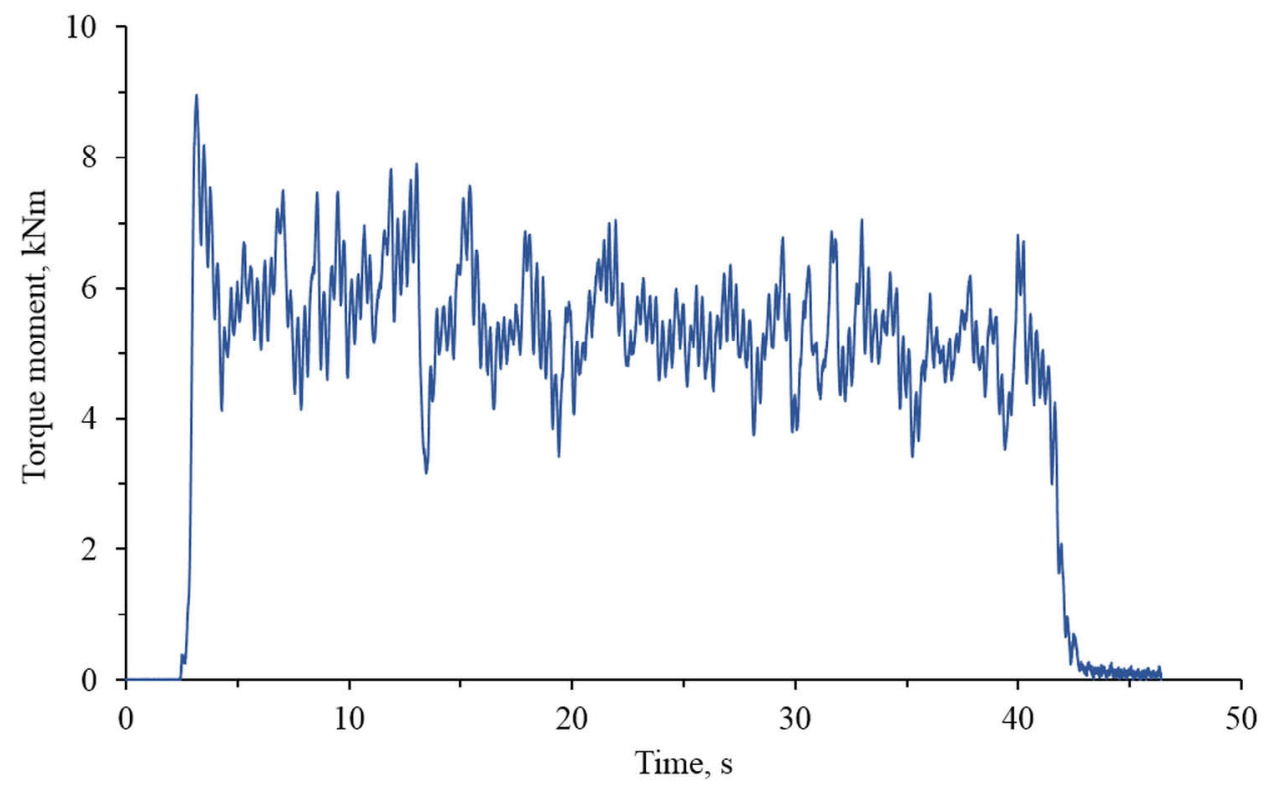

Fig. 8. Time characteristics of the torque moment on a roll press, measured at $v_{\mathrm{r}}=0.1 \mathrm{~m} / \mathrm{s}$. 
Mass performance of roll press equipped with saddle-shaped forming cavity rings $W_{\mathrm{b}}$ was determined by the relation:

$$
W_{\mathrm{b}}=60 \cdot V_{\mathrm{b}} i_{\mathrm{b}} n_{\mathrm{r}} \rho_{\mathrm{b}}, \mathrm{Mg} / \mathrm{h},
$$

where: $V_{\mathrm{b}}$ - briquette volume, $\mathrm{m}^{3} ; i_{\mathrm{b}}$ - cavities quantity, $i_{\mathrm{b}}=90,-; n_{\mathrm{r}}$ - roll press rotational speed, rpm; $\rho_{b}$ - briquette density, $\mathrm{Mg} / \mathrm{m}^{3}$.

Unit energy demand of briquetting process $\left(Z_{\mathrm{e}}\right)$ was determined by the equation:

$$
Z_{\mathrm{b}}=N_{\mathrm{b}} / W_{\mathrm{b}}, \mathrm{kWh} / \mathrm{Mg}
$$

where: $N_{\mathrm{b}}$ - power consumed during briquetting process, $\mathrm{kW} ; W_{\mathrm{b}}$ - mass yield of the roll press, $\mathrm{Mg} / \mathrm{h}$.

Passing the material twice through the rolls of press caused unit pressure in the cavity forming to reach up to $246 \mathrm{MPa}$ (Fig. 9).

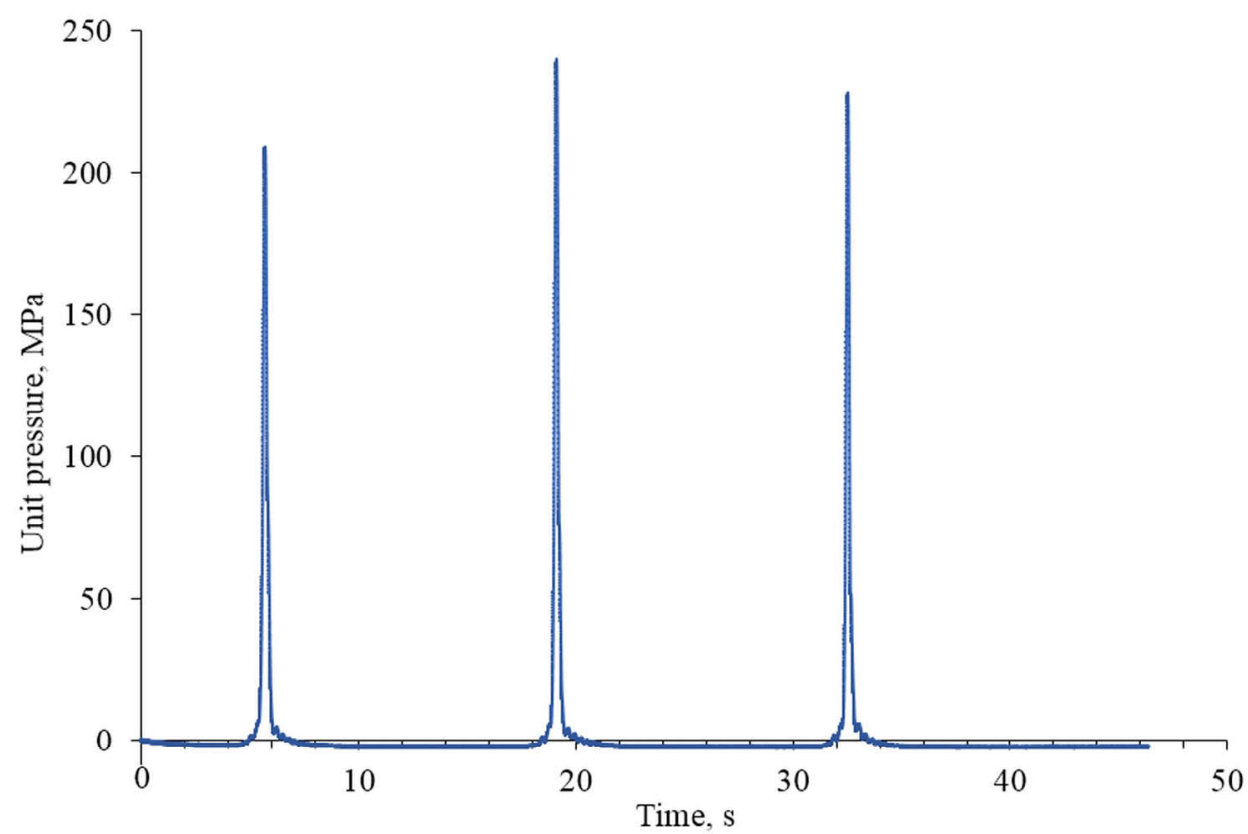

Fig. 9. Time characteristics of unit pressure in a forming cavities, measured at $v_{\mathrm{r}}=0.1 \mathrm{~m} / \mathrm{s}$.

This information may be crucial in the preparation of guidelines for the design of industrial lines of merging FGD gypsum without drying the material. Compressive strength of briquettes after $168 \mathrm{~h}$ was $0,472-0,536 \mathrm{MPa}$ while their density was contained in the range of $1.83-1.96 \mathrm{~g} / \mathrm{cm}^{3}$.

The study was then performed on the second roll-press LPW 1100 with rolls diameter $\mathrm{d}=1100 \mathrm{~mm}$, with a compaction system allowing production of briquettes in the shape of a saddle with a volume of approx. $85 \mathrm{~cm}^{3}$. FGD gypsum from Bełchatów power plants briquettes produced in roll press LPW 450 and LPW 1100 is presented in Fig. 10. 


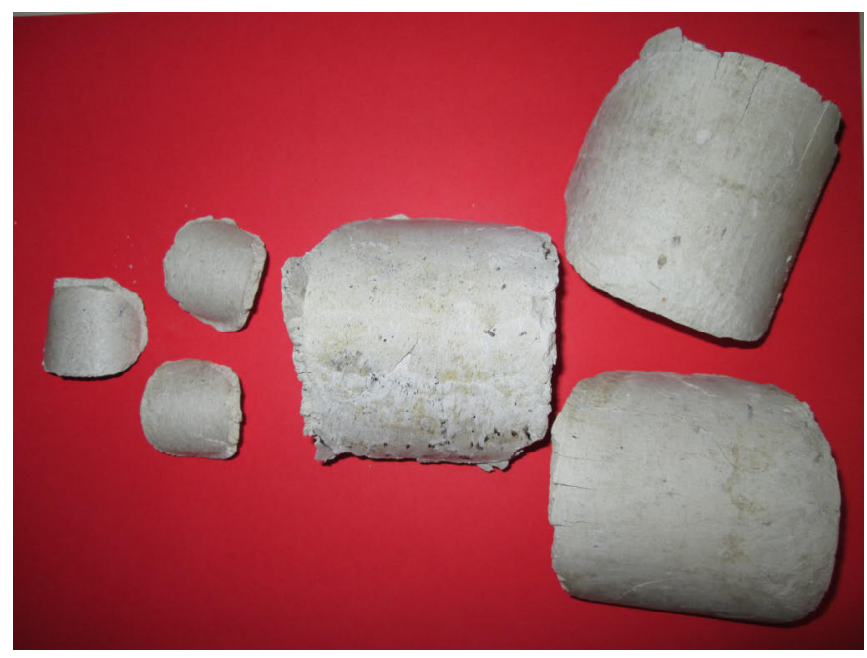

Fig.10. FGD gypsum from Bełchatów power plants briquettes produced in roll press LPW 450 (volume-6,5 $\mathrm{cm}^{3}$ ) and LPW 1100 (volume- $85 \mathrm{~cm}^{3}$ ).

Briquetting was cast on FGD gypsum with various humidity. After compacting briquettes were left to age for a period of 72 hours in a covered area at a temperature of $18-20{ }^{\circ} \mathrm{C}$. Figure 11 shows the influence of humidity on the strength of gypsum waste dump briquettes after aging.

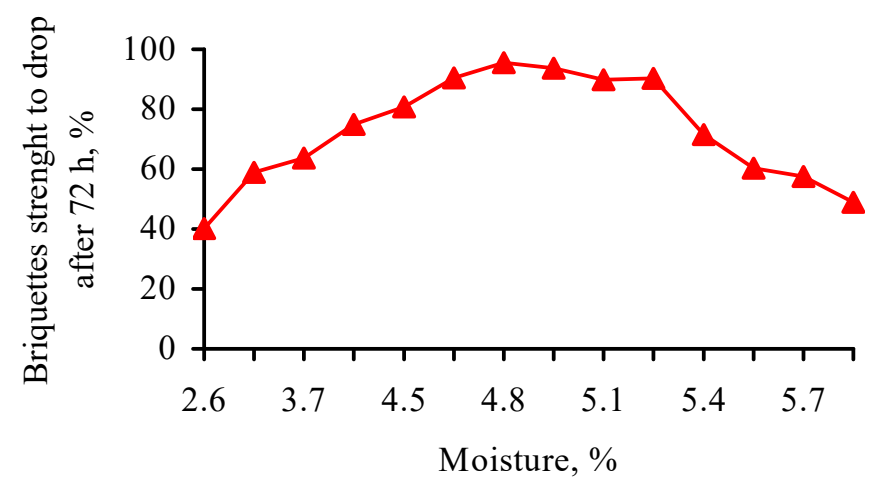

Fig.11. Relationship between briquettes' discharge strength and moisture of FDG gypsum briquetted in LPW 1100 roll press obtained from Bełchatów power plant.

Granted that the minimal discharge strength of the briquettes shouldn't be lower than $90 \%$, it was estimated that the moisture level between 4.6 to $5.2 \%$ is the most beneficial for the FDG gypsum.

It should be noted that briquettes received in the LPW 1100 press are nearly 12 times higher in volume than those received in LPW 450. In such case lower humidity of briquetting material is conductive to obtain material with higher unitary pressure.

Positive results of laboratory tests of FGD gypsum from Bełchatów power plant were the inspiration for trial briquetting in industrial conditions. For this purpose, the third roll-press was chosen - PW 500. It was designed by a team of the University employees. Chosen parameters of the industrial press PW 500 are shown as below:

- volumetric efficiency $\mathrm{Q}=3 \mathrm{~m}^{3} / \mathrm{h}$, 
- pitch diameter for rollers $\mathrm{D}_{\mathrm{p}}=500 \mathrm{~mm}$,

- rotational speed for rollers $\mathrm{n}_{\mathrm{w}}=11.5 \mathrm{rpm}$,

- molding cavities shape - saddle,

- briquette volume $\mathrm{V}_{\mathrm{b}}=13 \mathrm{~cm}^{3}$,

- material hopper - gravity feed.

Tests carried out on an industrial scale confirmed the results. In order to obtain positive results it was necessary to ensure adequate moisture of the FGD gypsum. Best quality briquettes were obtained in a narrow range of 5.2-6.5\% moisture. Performance of roll press PW 500 reached approx. $6.5 \mathrm{Mg} / \mathrm{h}$ briquetted material. The amount of undersize, which was successfully returned to the briquetting ranged from $10-15 \%$. Based on the industrial tests results a concept of the transmission line of FGD gypsum from Bełchatów power plant was developed - Fig. 12.

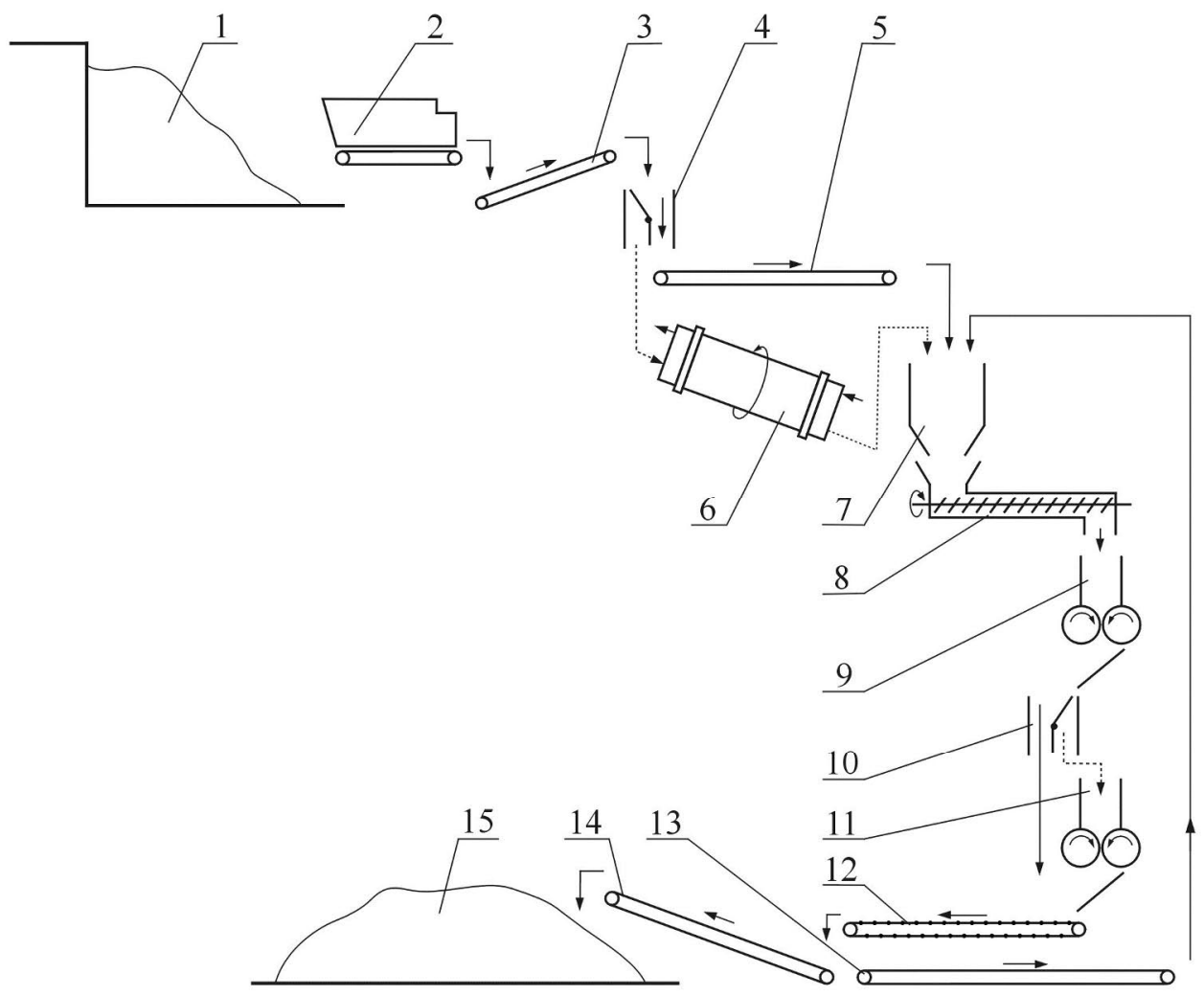

Fig. 12. Concept of the transmission line of FGD gypsum

1 - open landfill gypsum from flue gas desulphurization, 2 - box feeder, 3 - belt conveyor, 4 - twoway-distributor, 5 - belt conveyor, 6 - drum drier, 7 - one-dump bunker, 8 - screw feeder, 9 - roll press, 10 - two-way-distributor, 11 - roll press, 12 - transfer conveyor, 13,14 - belt conveyor, 15 landfill of briquettes.

\section{Conclusion}

FGD gypsum from Połaniec power plants and Bełchatów power plants may be used as a material for briquetting in a roll-press equipped with a merging system capable of producing briquetted in a saddle shape. The quality of briquettes obtained from FGD 
gypsum depended on the moisture content and the configuration of the roll-press. Humidity of Połaniec power plants. FGD gypsum range of 5.0-6.9\% formed by single pass through roll-press LPW 450, rotating at a peripheral speed of $0.3 \mathrm{~m} / \mathrm{s}$ allowed to obtain briquettes with strength to drop more than $80 \%$. Same strength to drop can be obtained by using Bełchatów power plants FGD gypsum with moisture content of 4.9-7.5\%. With higher humidity content $21.5-25.0 \%$ material should be passed through roll-press twice. The highest strength to drop was obtained by briquettes formed in a roll press equipped with a second variant of forming rings. In case of gypsum with moisture content exceeding $25.0 \%$ briquettes were not obtained as the material adhered to the forming rings. The test results can be used to determine the initial design assumptions for the briquetting line of FGD gypsum. Such work should focus on the moisture content of the material, configuration of the roll-press, peripheral speed of the rollers and the chemical composition of compacted material. Briquettes made of FGD gypsum obtain sufficient strength to drop during aging process. The time needed depends on the conditions of disposal. FGD gypsum products as a new material may be used in agriculture [7] and building industry [8].

Acknowledgements This article has been prepared within the scope of statutory activity, Contract No. 11.11.130.957.

\section{References}

1. Directive 2010/75/EU of the European Parliament and of the Council (OJ L 334, 24.11.2010, p. 17)

2. Statistical Yearbook of Industry 2014, 2015, Warsaw

3. T. Pająk, M. Jurczyk, M. Cyranka, Przem. Chem., 94, 1544-1547 (2014)

4. A. Magdziarz, M. Wilk, B. Kosturkiewicz, Chem. Proc. Eng., 32, 299-309 (2011)

5. S.R. Richards, Fuel Process. Technol., 25, 89-100, (1990)

6. S.J. Mangena, V.M. du Cann, Int. J. Coal Geol., 71, 303-312, (2007)

7. A. Kaczor, J. Zuzańska, Chem.-Did.-Ecol.-Metrol., 14, 69-78 (2009)

8. J.J. Hycnar, G. Borowski, T. Józefiak, A. Malec, Ecol. Eng., 45, 51-58 (2015) 